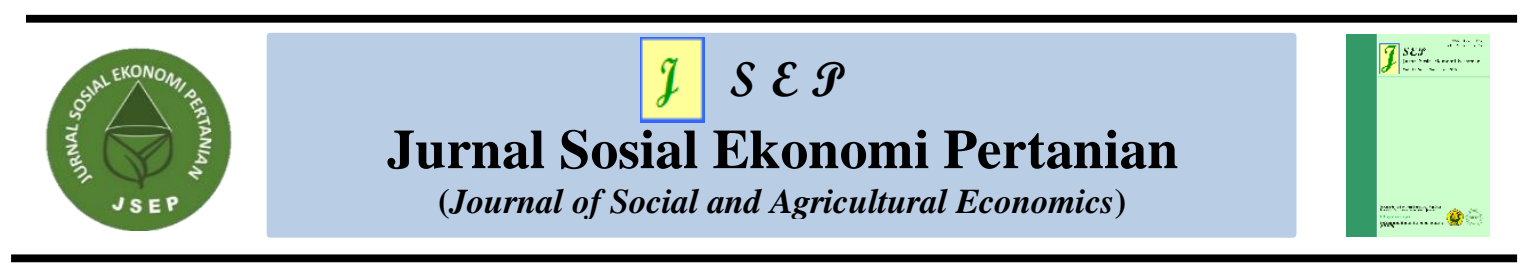

\title{
OPTIMALISASI USAHATANI SAYUR TUMPANGSARI DI DESA SUKORAMBI KECAMATAN SUKORAMBI KABUPATEN JEMBER
}

\section{OPTIMIZATION OF INTERCROPPING VEGETABLE FARMING IN SUKORAMBI VILLAGE, DISTRICT OF SUKORAMBI, JEMBER REGENCY}

\author{
Berilisda Jepatrika Dirga Buana $^{{ }^{*}}$, Anik Suwandari ${ }^{1}$ \\ ${ }^{1}$ Program Studi Agribisnis Fakultas Pertanian, Universitas Jember \\ *email: jepatrika@gmail.com
}

Naskah diterima: 27/12/2019 Naskah direvisi: 02/07/2020 Naskah diterbitkan: 31/07/2020

\begin{abstract}
The implementation of intercropping systems is considered by farmers to be able to overcome the problem of low productivity and fluctuations in vegetable prices. The purpose of this study was to determine Combination of intercropping vegetable farming that provides maximum benefits. The determination of the study area was carried out using a purposive method. The sampling technique uses quota sampling. The method of analysis uses linear programming. The results showed that (1) the maximum benefit of the intercropping model 1 was obtained by planting green mustard and spinach, the intercropping model 2 planting green mustard, spinach and kale, the intercropping model 3 planting green mustard, spinach and basil, the intercropping model 4 planting spinach, green mustard, marigolds and basil. (2) Rare production factors are spinach land on intercropping models 1, 2, 3 and 4, basil land on intercropping model 4, ZA fertilizer on intercropping model 1, manure on intercropping models 2, 3 and 4, callicron pesticide on intercropping model 2 and 4 as well as the amnistar top pesticides in intercropping model 3. (3) The highest increase in maximum profit conditions is in the intercropping model 4 by $15.7 \%$ and the lowest in the intercropping model 1 by $13.6 \%$.
\end{abstract}

Keywords: intercropping vegetable farming, linear programming, optimization

\begin{abstract}
ABSTRAK
Penerapan sistem tanam tumpangsari dinilai petani dapat mengatasi masalah produktivitas rendah dan fluktuasi harga sayur. Tujuan dari penelitian ini adalah untuk mengetahui kombinasi usahatani sayur tumpangsari yang memberikan keuntungan maksimal. Penentuan daerah penelitian dilakukan dengan purposive method. Teknik pengambilan sampel menggunakan quota sampling. Metode analisis menggunakan linear programming. Hasil penelitian menunjukkan bahwa (1) Keuntungan maksimal model tumpangsari 1 diperoleh dengan menanam sayur sawi dan bayam, model tumpangsari 2 menanam sayur sawi, bayam dan kangkung, model tumpangsari 3 menanam sayur sawi, bayam dan kemangi, model tumpangsari 4 menanam sayur bayam, sawi, kenikir dan kemangi. (2) Faktor produksi langka yaitu lahan bayam pada tumpangsari model 1, 2, 3 dan 4, lahan kemangi pada tumpangsari model 4, pupuk ZA pada tumpangsari model 1, pupuk kandang pada tumpangsari model 2, 3 dan 4, pestisida callicron pada tumpangsari model 2 dan 4 serta pestisida amnistar top pada tumpangsari model 3. (3) Peningkatan keuntungan tertinggi pada kondisi keuntungan maksimal yaitu pada model tumpangsari 4 sebesar 15,7 \% dan terendah pada model tumpangsari 1 sebesar 13,6\%.
\end{abstract}

Kata kunci: linear programming, optimalisasi, sistem tanam tumpangsari

How to Cite: Buana, B.J.D., Suwandari, A. (2020). Optimalisasi Usahatani Sayur Tumpangsari di Desa Sukorambi Kecamatan Sukorambi Kabupaten Jember. JSEP: Jurnal Sosial Ekonomi Pertanian, 13(2): $125-144$

125 Optimalisasi Usahatani Sayur Tumpangsari. . . .

Berilisda J. D.B. \& Anik Suwandari 


\section{PENDAHULUAN}

Perkembangan subsektor hortikultura telah memberikan sumbangan terhadap kemajuan perekonomian nasional yang dapat dilihat dari kontribusinya terhadap nilai Produk Domestik Bruto (PDB) dan sumber utama pendapatan rumah tangga perdesaan. Menurut data Badan Pusat Statistik tahun 2018, PDB sub sektor hortikultura atas dasar harga berlaku pada tahun 2017 mengalami peningkatan mencapai Rp196.132 milyar dengan laju pertumbuhan sebesar 4,66\%, apabila dibandingkan dengan PDB hortikultura tahun 2016 sebesar Rp187.403 milyar. Salah satu komoditas yang berkontribusi terhadap perkembangan subsektor hortikultura adalah sayuran. Komoditas sayuran memiliki peran yang penting untuk kebutuhan konsumsi dan pengembangan ekonomi bagi masyarakat. Sayur memiliki berbagai manfaat yang terkandung didalamnya seperti vitamin, mineral dan serat yang berguna sebagai asupan makanan sehari-hari untuk memenuhi gizi seimbang. Peranan penting komoditas sayuran dalam pengembangan ekonomi masyarakat antara lain sebagai sumber pendapatan, bahan baku industri, penyerapan tenaga kerja dan sebagai komoditas ekspor yang dapat menjadi sumber devisa negara. Konsumsi sayur yang terus mengalami peningkatan setiap tahunnya masih belum mencapai tingkat konsumsi sayur yang direkomendasikan oleh Organisasi Kesehatan Dunia (WHO) dan Organisasi Pangan Dunia (FAO) pada tahun 2003.

Menurut hasil survey sosial ekonomi nasional yang dilakukan oleh Badan Pusat Statistik pada tahun 2016, konsumsi sayur per kapita pada tingkat nasional sebanyak 107 gram dalam sehari. Nilai konsumsi tersebut masih belum memenuhi angka kecukupan gizi (AKG) yang direkomendasikan WHO dan FAO yaitu sebesar 400 gram perkapita perhari. Program-program edukasi telah banyak digencarkan oleh pemerintah mengenai pentingnya mengkonsumsi sayuran diantaranya melalui program Gerakan Masyarakat Hidup Sehat (GERMAS) yang dilakukan oleh Kementerian Kesehatan Republik Indonesia. Hal tersebut menjadi peluang bagi petani sayur untuk terus meningkatkan produksi sayurnya. Ketersediaan sayur untuk konsumsi disumbangkan dari Pulau Jawa karena beberapa provinsi di Pulau Jawa merupakan sentra penghasil jenis sayur yang paling banyak dikonsumsi oleh masyarakat. Berdasarkan data Badan Pusat Statistik tahun 2018, provinsi di Pulau Jawa dengan produksi sayuran yang mengalami peningkatan di beberapa jenis sayuran pada tahun 2018 salah satunya adalah Provinsi Jawa Timur. Provinsi Jawa Timur menempati urutan ke dua jumlah produksi tertinggi sayur bayam, kacang panjang, dan terung serta menempati urutan ke tiga jumlah produksi tertinggi sayur kangkung di Pulau Jawa pada tahun 2018. Hal tersebut mengindikasikan bahwa komoditas sayuran memiliki peluang yang bagus untuk lebih dikembangkan di Jawa Timur. Peningkatan produksi sayur di Jawa Timur juga didukung oleh Dinas Pertanian Provinsi Jawa Timur melalui Masterplan Pengembangan Kawasan Tanaman Pangan dan Hortikultura Jawa Timur tahun 2015 hingga tahun 2019 dengan penerapan GAP (Good Agriculture Practice) dan PTT (Pengelolaan Tanaman Terpadu) pada tanaman sayur.

Salah satu kabupaten di Jawa Timur dengan produktivitas sayur yang masih rendah jika dibandingkan dengan kabupaten lainnya di Jawa Timur adalah Kabupaten Jember. Menurut data Dinas Pertanian Jawa Timur (2018), luas tanam sayur bayam di Kabupaten Jember lebih besar dari Kabupaten Banyuwangi dan Tulungagung, akan tetapi produksi sayur bayam di Kabupaten Jember lebih rendah dari Kabupaten Banyuwangi dan Kabupaten Tulungagung. Hal tersebut juga terjadi pada sayur kangkung dan sayur sawi. Pada sayur kangkung, luas tanam di Kabupaten Jember lebih besar dari Kabupaten Lumajang, Kabupaten Banyuwangi, Kabupaten Kediri dan Kabupaten Pasuruan, akan tetapi produksi sayur kangkung di Kabupaten Jember lebih rendah dari 4 Kabupaten yang memiliki luas tanam yang lebih rendah dari Kabupaten Jember. Pada tanaman sawi, Kabupaten Tulungagung dan Kabupaten Nganjuk yang luas tanamnya lebih rendah dari Kabupaten Jember juga memiliki produksi sayur sawi yang lebih tinggi dari Kabupaten Jember. Hal tersebut menunjukkan Kabupaten Jember memiliki produktivitas sayur yang masih rendah. Pengembangan komoditas sayur di Kabupaten Jember tidak hanya terkendala dari produktivitas yang masih rendah. Harga sayur yang berfluktuasi juga menjadi kendala bagi para petani sayur untuk mendapatkan keuntungan maksimal.

Salah satu wilayah di Kabupaten Jember yang menjadi sentra produksi tanaman sayur adalah di Desa Sukorambi Kecamatan Sukorambi. Jumlah produksi sayur menurut jenis sayuran pada beberapa kecamatan penghasil sayur di Kabupaten Jember dapat dilihat pada tabel berikut. 
Tabel 1. Produksi Sayur Menurut Jenis Sayuran pada beberapa Kecamatan di Kabupaten Jember pada Tahun 2018.

\begin{tabular}{rlrrr}
\hline \multirow{2}{*}{ No } & \multirow{2}{*}{ Kecamatan } & \multicolumn{3}{c}{ Produksi (kw) } \\
\cline { 3 - 5 } & & Bayam & \multicolumn{1}{c}{ Sawi } & Kangkung \\
\hline 1 & Balung & - & 1.240 & 267 \\
2 & Panti & 992 & 3.792 & 930 \\
3 & Sukorambi & 1.190 & 5.714 & 1.520 \\
4 & Kaliwates & 372 & 1.088 & 368 \\
5 & Ledokombo & 861 & - & 837 \\
\hline
\end{tabular}

Sumber : Badan Pusat Statistik Kabupaten Jember (2019)

Usahatani sayur dilakukan di Desa Sukorambi karena dinilai memiliki kondisi lahan yang subur dan sesuai untuk usahatani sayur dataran rendah. Salah satu upaya yang dilakukan oleh petani di Desa Sukorambi untuk dapat mengatasi kendala produktivitas rendah dan fluktuasi harga sayur adalah dengan menerapkan usahatani sayur sistem tanam tumpangsari. Sistem tanam tumpangsari sayur yang diterapkan petani yaitu dengan menanam 2 hingga 5 jenis sayuran dalam satu kali penanaman. Jenis sayur yang banyak ditumpangsarikan yaitu sayur bayam, sawi, kangkung, kemangi dan kenikir dengan membagi lahan menjadi beberapa bedengan-bedengan. Pemilihan jenis tanaman yang bervariasi tidak menjamin petani dapat memperoleh keuntungan yang maksimal jika sayur yang ditanam dan faktor produksi yang digunakan tidak dialokasikan secara tepat. Penentuan jenis sayur yang berjumlah 2 hingga 5 tanaman dalam satu lahan dan memiliki jumlah produksi serta harga jual yang berbeda-beda menjadi permasalahan petani untuk memperoleh keuntungan yang maksimal.

Petani dalam menentukan jenis sayur yang ditanam dalam satu lahan juga dibatasi oleh faktor produksi yang dapat disediakan oleh petani. Alokasi faktor produksi akan semakin sulit dilakukan karena bervariasinya jenis sayur pada setiap penanaman dan setiap jenis sayur memiliki faktor produksi dengan ukuran dan biaya yang berbeda-beda. Keterbatasan faktor produksi tersebut antara lain keterbatasan luas lahan, modal, jumlah benih, jumlah pupuk, waktu tenaga kerja dan jumlah pestisida yang dapat disediakan oleh petani. Penentuan jenis sayur yang ditanam dengan alokasi faktor produksi yang tersedia secara tepat merupakan suatu hal yang harus dilakukan agar petani di Desa Sukorambi dapat memperoleh keuntungan yang maksimal. Penelitian sebelumnya terkait dengan optimalisasi usahatani sayuran yang telah dilakukan oleh Idani (2012) dengan judul "Analisis Pendapatan Usahatani dan Optimalisasi Pola Tanam Sayuran Di Kelompok Tani Pondok Menteng Desa Citapen, Kecamatan Ciawi Kabupaten Bogor, Jawa Barat" menjelaskan pola tanam optimal yang dianjurkan untuk diterapkan oleh petani pada 3 musim tanam dalam satu tahun.

Peneliti pada mulanya menentukan jenis sayuran apa saja yang ditanam petani pada musim tanam 1, musim tanam 2 dan musim tanam 3 baik yang ditanam secara monokultur maupun tumpangsari dalam kondisi aktual. Semua jenis sayuran yang telah dikelompokkan pada setiap musim tanamnya tersebut, kemudian dilakukan analisis untuk memilih jenis sayuran yang dapat memberikan keuntungan maksimal untuk ditanam pada musim tanam 1, musim tanam 2 dan musim tanam 3. Hasil analisis tersebut menunjukkan satu kombinasi sayuran tumpangsari pada setiap musim tanam yang dapat menghasilkan kondisi pola tanam optimal. Penelitian lainnya terkait optimalisasi usahatani sayuran yang telah dilakukan oleh Djafri et al (2017) dengan judul "Optimasi Produksi Usahatani Sayuran Organik (Studi Kasus Yayasan Bina Sarana Bakti, Cisarua, Bogor)" menjelaskan optimalisasi pola tanam sayuran organik yang didasarkan pada usia tanaman. Peneliti terlebih dahulu menentukan jenis sayur yang ditanam pada kondisi aktual dan mengelompokkan sayuran tersebut berdasarkan usia tanaman yaitu usia 6 minggu, 8 minggu, 10 minggu dan 12 minggu. Tahapan analisis dilakukan untuk memilih jenis sayuran organik pada setiap usia tanaman yang dapat 
menghasilkan pola tanam optimal. Hasil analisis menunjukkan bahwa terdapat pengurangan jumlah sayur yang ditanam pada setiap usia tanaman untuk memperoleh keuntungan maksimal.

Penelitian-penelitian yang telah dilakukan sebelumnya terkait optimalisasi usahatani sayuran memiliki perbedaan dengan penelitian ini, dimana tujuan dari penelitian ini adalah untuk melakukan analisis optimalisasi pada masing-masing kombinasi sayuran yang telah ditentukan. Peneliti terlebih dahulu menentukan jenis sayuran yang paling banyak ditanam oleh petani dengan mengelompokkan sayuran tersebut berdasarkan sistem tanam tumpangsari yang terdiri dari 4 kelompok yaitu kelompok sayuran dengan jumlah 2 sayuran, 3 sayuran, 4 sayuran dan 5 sayuran dalam satu lahan. Pemilihan jumlah sayuran dalam satu lahan tersebut didasarkan pada kondisi usahatani sayur di Desa Sukorambi yang menanam 2 hingga 5 sayuran dalam satu lahan. Analisis dilakukan pada masing-masing kelompok sayuran sehingga akan menghasilkan kombinasi sayuran yang harus ditanam pada setiap kelompok sayuran untuk mendapatkan keuntungan maksimal. Hal tersebut yang menunjukkan perbedaan penelitian ini dengan penelitian sebelumnya. Penelitian yang dilakukan oleh Idani pada tahun 2012 adalah memilih kombinasi jenis sayuran yang dapat memberikan keuntungan maksimal diantara banyak pilihan kombinasi sayuran yang ditanam setiap musimnya dan penelitian yang dilakukan oleh Djafri dkk pada tahun 2016 mengelompokkan jenis sayuran organik berdasarkan usia tanaman untuk menentukan jenis sayuran yang ditanam untuk memperoleh keuntungan maksimal, sedangkan penelitian ini melakukan analisis untuk semua kelompok sayuran yang dibagi berdasarkan jumlah sayur yang ditanam sehingga dapat diketahui jenis sayuran yang dapat memberikan keuntungan maksimal untuk setiap kelompok sayuran dalam satu kali tanam. Berdasarkan permasalahan-permasalahan yang telah dijelaskan, dapat dirumuskan beberapa rumusan masalah yaitu (1) Bagaimana kombinasi usahatani sayur tumpangsari yang memberikan keuntungan maksimal bagi petani sayur di Desa Sukorambi. (2) Bagaimana penggunaan faktor produksi usahatani sayur tumpangsari di Desa Sukorambi. (3) Bagaimana kondisi aktual dan kondisi maksimal keuntungan usahatani sayur tumpangsari di Desa Sukorambi. Penelitian ini bertujuan untuk mengetahui (1) Kombinasi tanaman sayur tumpangsari pada petani yang memberikan keuntungan maksimal, (2) Penggunaan faktor produksi usahatani sayur tumpangsari, (3) Kondisi aktual dan kondisi maksimal keuntungan usahatani sayur tumpangsari.

\section{METODE PENELITIAN}

Pemilihan lokasi penelitian dilakukan secara sengaja (purposive). Menurut Rianse dan Abdi (2012), metode purposive merupakan metode penentuan lokasi penelitian secara sengaja dengan pertimbangan-pertimbangan yang logis. Daerah penelitian yang dipilih adalah Desa Sukorambi Kecamatan Sukorambi Kabupaten Jember. Lokasi penelitian tersebut dipilih atas dasar pertimbangan bahwa Desa Sukorambi Kecamatan Sukorambi berkontribusi tinggi dalam memproduksi sayur di Kabupaten Jember. Berdasarkan data Badan Pusat Statistik Kabupaten Jember pada tahun 2018, jenis sayuran yang diproduksi di Kecamatan Sukorambi yaitu sayur bayam dengan tingkat produksi sebesar $1.190 \mathrm{kw}$, sayur sawi sebesar $5.714 \mathrm{kw}$ dan sayur kangkung sebesar $1.520 \mathrm{kw}$. Petani sayur di Desa Sukorambi Kecamatan Sukorambi menanam tanaman sayur dengan sistem tanam tumpangsari. Komoditas sayur yang ditanam berjumlah 2 hingga 5 jenis sayur dalam satu lahan. Jenis sayur yang ditanam antara lain sayur sawi, bayam, kangkung, kenikir dan kemangi.

Metode yang digunakan dalam penelitian ini adalah metode deskriptif dan metode analitis. Metode deskriptif digunakan untuk melukiskan secara akurat sifat-sifat dari beberapa fenomena kelompok atau individu (Nazir, 1988). Metode deskriptif pada penelitian ini digunakan untuk memberikan gambaran mengenai usahatani sayur tumpangsari di Desa Sukorambi Kecamatan Sukorambi Kabupaten Jember. Metode analitis adalah metode yang 
digunakan untuk menguji hipotesa-hipotesa dan mengadakan interpretasi yang lebih mendalam tentang hubungan-hubungan (Nazir, 1988). Metode analitis digunakan untuk mengetahui jenis tanaman sayur yang harus ditanam pada setiap model tumpangsari untuk mencapai keuntungan maksimal, untuk mengetahui optimalisasi faktor produksi usahatani sayur tumpangsari dan untuk mengetahui kondisi keuntungan aktual dan kondisi keuntungan maksimal pada usahatani sayur tumpangsari di Desa Sukorambi Kecamatan Sukorambi Kabupaten Jember.

Penelitian dilakukan pada musim kemarau di mulai dari bulan April tahun 2019. Metode pengambilan contoh yang digunakan dalam penelitian ini adalah non probability sampling. Non probability sampling adalah pengambilan sampel yang tidak memberikan peluang yang sama bagi setiap unsur (anggota) populasi untuk dipilih menjadi anggota sampel. Populasi dalam penelitian ini bersifat heterogen yang dibedakan berdasarkan kombinasi sayur pada setiap model tumpangsari yang berbeda. Teknik pengambilan sampel menggunakan quota sampling. Quota sampling lebih mementingkan pada tujuan penelitian dalam menentukan sampling penelitian. Teknik penarikan sampel menggunakan quota sampling dilakukan dengan cara membagi populasi menjadi beberapa strata sesuai dengan fokus penelitian dimana jumlah populasi tiap strata tidak diketahui (Lupiyoadi, R dan Ikhsan, $\mathrm{R}, 2015)$. Subjek yang diambil sebagai sampel apakah mewakili atau tidak mewakili populasi atau sub populasi bukan menjadi persoalan (Marzuki, 1983). Tujuan penelitian adalah menganalisis 4 kelompok usahatani sayur tumpangsari untuk memperoleh keuntungan maksimal. Sampel dibagi kedalam 4 kelompok yaitu model tumpangsari 1, model tumpangsari 2, model tumpangsari 3 dan model tumpangsari 4, dimana setiap kelompok memiliki jumlah sampel sebanyak 15 sampel sehingga total sampel yang digunakan sebanyak 60 sampel.

Data pada penelitian ini menggunakan data primer dan data sekunder. Data primer adalah data yang didapat dari sumber pertama atau sumber asli (langsung dari informan), sedangkan data sekunder adalah data yang diambil dari sumber kedua atau bukan dari sumber aslinya (Rianse dan Abdi, 2012). Data primer merupakan data mentah yang diproses untuk tujuan tertentu sesuai dengan kebutuhan. Sumber data sekunder dapat berasal dari peneliti sebelumnya, lembaga pemerintah dan lembaga swasta. Data yang tersaji pada data sekunder dapat berupa tabel dan grafik. Teknik pengumpulan data yang digunakan adalah wawancara, observasi dan dokumentasi (Bungin, 2013). Data yang diperoleh dari wawancara adalah data produksi sayur, harga sayur, biaya usahatani sayur tumpangsari, jumlah kebutuhan faktor produksi yang digunakan seperti lahan, pupuk, pestisida, benih, modal dan tenaga kerja, serta data terkait kondisi usahatani sayur tumpangsari di Desa Sukorambi. Observasi dilakukan untuk mengetahui secara langsung kejadian yang sebenarnya terjadi dilokasi penelitian serta dapat digunakan untuk melengkapi informasi dan data dari hasil wawancara. Data sekunder pada penelitian ini diperoleh dari Badan Pusat Statistik, data Kementerian Pertanian dan literatur-literatur yang berasal dari buku, jurnal, skripsi dan artikel ilmiah.

Analisis data yang digunakan pada permasalahan dalam penelitian ini mengenai kombinasi sayur tumpangsari yang dapat memberikan keuntungan maksimal, penggunaan faktor produksi serta kondisi aktual dan kondisi maksimal keuntungan usahatani sayur tumpangsari dianalisis dengan metode linear programming. Perhitungan dilakukan dengan bantuan software QM for Windows. Analisis pada seluruh model tumpangsari dihitung dalam ukuran luas lahan $10.000 \mathrm{~m}^{2}$ untuk masing-masing sayur. Ukuran luas lahan tersebut merupakan ukuran objektif yang digunakan dalam pengambilan keputusan (Sari, 2018). Petani dapat menggunakan ukuran luas lahan tersebut sebagai dasar melakukan perencanaan terhadap usahatani sayur dengan luas lahan yang lebih kecil atau lebih besar dari $10.000 \mathrm{~m}^{2}$. Hasil analisis adalah untuk setiap rumah tangga petani yang akan menerapkan usahatani sayur tumpangsari sesuai dengan model tumpangsari yang diterapkan. Analisis data dengan 
menggunakan linear programming terdapat tiga unsur utama yang harus ditentukan yaitu menentukan variabel keputusan, fungsi tujuan dan fungsi keterbatasan atau kendala.

1. Menentukan Variabel Keputusan

Variabel keputusan menunjukkan kegiatan usahatani sayur sistem tanam tumpangsari yang dilakukan oleh petani sayur di Desa Sukorambi. Kombinasi tanaman sayur yang dipilih pada setiap model tumpangsari merupakan komoditas sayur yang memiliki luas tanam dan produksi tertinggi. Urutan pemilihan jenis sayur pada setiap model tumpangsari mulai dari sayur yang memiliki luas tanam dan produksi tertinggi yaitu sayur sawi, bayam, kangkung, kemangi dan kenikir. Variabel keputusan usahatani sayur tumpangsari dapat dilihat pada Tabel 2.

Tabel 2. Variabel Keputusan Usahatani Sayur Sistem Tanam Tumpangsari

\begin{tabular}{cll}
\hline No & \multicolumn{1}{c}{ Model Tumpangsari } & \multicolumn{1}{c}{ Komoditas Sayur } \\
\hline 1 & Tumpangsari 1 & Sawi + Bayam \\
2 & Tumpangsari 2 & Sawi + Bayam + Kangkung \\
3 & Tumpangsari 3 & Sawi + Bayam + Kangkung + Kemangi \\
4 & Tumpangsari 4 & Sawi + Bayam + Kangkung + Kemangi + Kenikir \\
\hline
\end{tabular}

2. Menentukan Fungsi Tujuan

Fungsi tujuan pada metode linear programming adalah suatu keinginan untuk mencapai kondisi yang dapat memberikan keuntungan maksimal. Fungsi tujuan yang ditentukan merupakan hubungan linier koefisien dengan variabel keputusan. Data yang digunakan untuk menentukan koefisien variabel keputusan pada fungsi tujuan adalah dari besarnya keuntungan yang diperoleh setiap jenis sayur. Fungsi tujuan dalam penelitian ini terbagi menjadi 4 yaitu fungsi tujuan keuntungan sayur pada model tumpangsari 1, tumpangsari 2, tumpangsari 3 dan tumpangsari 4. Fungsi tujuan dalam penelitian ini dapat dirumuskan sebagai berikut.

a. Memaksimumkan keuntungan model tumpangsari 1 :

Maksimum $\mathrm{Z}=\mathrm{C}_{1} \mathrm{X}_{1}+\mathrm{C}_{2} \mathrm{X}_{2}$

Keterangan :

$\mathrm{Z} \quad$ : Keuntungan tanaman sayur tumpangsari yang ingin dimaksimumkan (rupiah)

$\mathrm{C}_{1}-\mathrm{C}_{2} \quad$ : Keuntungan setiap tanaman sayur (rupiah)

$\mathrm{X}_{1} \quad$ : Sayur sawi

$\mathrm{X}_{2} \quad$ : Sayur bayam

b. Memaksimumkan keuntungan model tumpangsari 2 :

Maksimum $\mathrm{Z}=\mathrm{C}_{1} \mathrm{X}_{1}+\mathrm{C}_{2} \mathrm{X}_{2}+\mathrm{C}_{3} \mathrm{X}_{3}$

Keterangan :

$\mathrm{Z} \quad$ : Keuntungan tanaman sayur tumpangsari yang ingin dimaksimumkan (rupiah)

$\mathrm{C}_{1}-\mathrm{C}_{3} \quad$ : Keuntungan setiap tanaman sayur (rupiah)

$\mathrm{X}_{1} \quad$ : Sayur sawi

$\mathrm{X}_{2} \quad$ : Sayur bayam

$\mathrm{X}_{3} \quad$ : Sayur kangkung

c. Memaksimumkan keuntungan model tumpangsari 3 :

Maksimum $\mathrm{Z}=\mathrm{C}_{1} \mathrm{X}_{1}+\mathrm{C}_{2} \mathrm{X}_{2}+\mathrm{C}_{3} \mathrm{X}_{3}+\mathrm{C}_{4} \mathrm{X}_{4}$

Keterangan:

$\mathrm{Z} \quad$ : Keuntungan tanaman sayur tumpangsari yang ingin dimaksimumkan (rupiah)

$\mathrm{C}_{1}-\mathrm{C}_{4} \quad$ : Keuntungan setiap tanaman sayur (rupiah)

$\mathrm{X}_{1} \quad$ : Sayur sawi 


$\begin{array}{ll}\mathrm{X}_{2} & \text { : Sayur kangkung } \\ \mathrm{X}_{3} & \text { : Sayur bayam } \\ \mathrm{X}_{4} & \text { : Sayur kemangi }\end{array}$

d. Memaksimumkan keuntungan model tumpangsari 4 :

Maksimum $\mathrm{Z}=\mathrm{C}_{1} \mathrm{X}_{1}+\mathrm{C}_{2} \mathrm{X}_{2}+\mathrm{C}_{3} \mathrm{X}_{3}+\mathrm{C}_{4} \mathrm{X}_{4}+\mathrm{C}_{5} \mathrm{X}_{5}$

Keterangan :

$\mathrm{Z} \quad$ : Keuntungan tanaman sayur tumpangsari yang ingin dimaksimumkan (rupiah)

$\mathrm{C}_{1}-\mathrm{C}_{5} \quad$ : Keuntungan setiap tanaman sayur (rupiah)

$\mathrm{X}_{1} \quad$ : Sayur bayam

$\mathrm{X}_{2} \quad$ : Sayur sawi

$\mathrm{X}_{3} \quad$ : Sayur kangkung

$\mathrm{X}_{4} \quad$ : Sayur kenikir

$\mathrm{X}_{5} \quad$ : Sayur kemangi

3. Menentukan Batasan

Keterbatasan-keterbatasan untuk memperoleh keuntungan maksimal pada setiap model usahatani sayur tumpangsari di Desa Sukorambi adalah keterbatasan luas lahan, pupuk, pestisida, benih, tenaga kerja dan modal.

\section{HASIL DAN PEMBAHASAN}

Analisis dilakukan selama 1 kali tanam pada musim kemarau di mulai pada bulan April tahun 2019 dengan luas lahan masing-masing sayur pada setiap model tumpangsari sebesar $10.000 \mathrm{~m}^{2}$. Jumlah hari untuk satu kali tanam pada sayur bayam adalah 30 hari mulai dari penyebaran benih hingga panen. Jumlah hari untuk satu kali tanam pada sayur kangkung dan kenikir adalah 35 hari mulai dari penyebaran benih hingga panen. Jumlah hari untuk satu kali tanam pada sayur sawi adalah 50 hari mulai dari pembibitan hingga panen. Jumlah hari untuk satu kali tanam pada sayur kemangi adalah 95 hari mulai dari pembibitan hingga panen. Aktivitas produksi sayur tumpangsari yang diusahakan oleh petani di Desa Sukorambi terbagi kedalam 4 kelompok model tumpangsari yang terdiri dari 2 tanaman tumpangsari, 3 tanaman tumpangsari, 4 tanaman tumpangsari dan 5 tanaman tumpangsari.

Tabel 3.Penerimaan Usahatani Sayur Tumpangsari dalam 1 Kali Tanam Luasan Lahan Setiap Sayur 1 Ha Pada Musim Kemarau Tahun 2019

\begin{tabular}{clrrr}
\hline $\begin{array}{c}\text { Model } \\
\text { Tumpangsari }\end{array}$ & \multicolumn{1}{c}{$\begin{array}{c}\text { Jenis } \\
\text { Sayuran }\end{array}$} & $\begin{array}{c}\text { Produktivitas } \\
(\mathrm{Kg} / \mathrm{Ha})\end{array}$ & Harga $(\mathrm{Rp} / \mathrm{Kg})$ & Penerimaan (Rp) \\
\hline \multirow{2}{*}{ Tumpangsari 1 } & Sawi & 33.088 & 8.696 & 287.722 .222 \\
& Bayam & 30.542 & 10.000 & 305.416 .667 \\
\hline \multirow{5}{*}{ Tumpangsari 2 } & Sawi & 30.954 & 8.696 & 269.166 .667 \\
& Bayam & 29.583 & 10.000 & 295.833 .333 \\
& Kangkung & 20.594 & 9.000 & 185.350 .000 \\
\hline \multirow{5}{*}{ Tumpangsari 3 } & Sawi & 32.294 & 8.696 & 280.815 .972 \\
& Kangkung & 22.764 & 9.000 & 204.875 .000 \\
& Bayam & 31.250 & 10.000 & 312.500 .000 \\
& Kemangi & 9.600 & 34.000 & 326.400 .000 \\
\hline & Bayam & 30.042 & 10.000 & 300.416 .667 \\
Tumpangsari 4 & Sawi & 33.414 & 8.696 & 290.567 .178 \\
& Kangkung & 21.664 & 9.000 & 194.975 .000 \\
& Kenikir & 17.622 & 7.700 & 135.691 .111 \\
& Kemangi & 9.950 & 34.000 & 338.300 .000 \\
\hline
\end{tabular}

Sumber : Data Primer diolah (2019)

131 Optimalisasi Usahatani Sayur Tumpangsari. . . . 
Penerimaan usahatani sayur tumpangsari merupakan perkalian antara produksi sayuran yang diperoleh petani dengan harga jual sayuran tingkat konsumen di pasar induk Kabupaten Jember. Harga sayur didasarkan pada harga setiap ikat sayur dan dikonversi kedalam harga sayur dengan ukuran berat $1 \mathrm{Kg}$. Penerimaan sayur tertinggi pada semua model tumpangsari adalah sayur kemangi pada model tumpangsari 4. Penerimaan terendah pada semua model tumpangsari adalah sayur kenikir pada model tumpangsari 4. Penerimaan masing-masing sayur pada setiap model tumpangsari sayur dapat dilihat pada Tabel 3.

Biaya-biaya yang diperlukan dalam kegiatan usahatani sayur tumpangsari dalam satu kali tanam meliputi biaya pembelian pupuk, benih, pestisida dan upah tenaga kerja luar keluarga. Usahatani sayur tumpangsari yang dilakukan petani di Desa Sukorambi rata-rata menggunakan dua orang tenaga kerja yang berasal dari dalam keluarga dan luar keluarga. Total biaya terbesar yaitu pada model tumpangsari 4 sebesar Rp676.718.247 dan total biaya terkecil yang dikeluarkan petani dalam usahatani sayur tumpangsari yaitu pada model tumpangsari 1 dengan total biaya sebesar Rp329.130.566. Biaya-biaya yang dikeluarkan oleh petani selama aktifitas usahatani sayur setiap model tumpangsari dapat dilihat pada Tabel 4 .

Tabel 4. Biaya Usahatani Sayur Tumpangsari dalam Satu Kali Tanam Luasan Lahan Setiap Sayur 1 Ha Pada Musim Kemarau Tahun 2019

\begin{tabular}{cccrrrr}
\hline $\begin{array}{c}\text { Model } \\
\text { Tumpangsari }\end{array}$ & $\begin{array}{c}\text { Biaya Pupuk } \\
(\mathrm{Rp})\end{array}$ & $\begin{array}{c}\text { Biaya } \\
\text { Pestisida } \\
(\mathrm{Rp})\end{array}$ & $\begin{array}{c}\text { Biaya } \\
\text { Benih (Rp) }\end{array}$ & $\begin{array}{c}\text { Biaya TK } \\
(\mathrm{Rp})\end{array}$ & $\begin{array}{c}\text { Penyusutan } \\
(\mathrm{Rp})\end{array}$ & $\begin{array}{c}\text { Total Biaya } \\
(\mathrm{Rp})\end{array}$ \\
\hline Tumpangsari 1 & 85.854 .233 & 2.633 .066 & 0 & 238.255 .200 & 2.388 .067 & 329.130 .566 \\
Tumpangsari 2 & 125.885 .258 & 4.997 .481 & 9.000 .000 & 225.612 .750 & 4.135 .800 & 369.631 .290 \\
Tumpangsari 3 & 172.753 .347 & 5.757 .047 & 9.000 .000 & 278.799 .292 & 4.266 .378 & 470.576 .064 \\
Tumpangsari 4 & 211.230 .328 & 6.802 .211 & 9.000 .000 & 445.271 .175 & 4.414 .533 & 676.718 .247 \\
\hline
\end{tabular}

Sumber : Data Primer diolah (2019)

Berdasarkan penerimaan dan biaya-biaya yang dikeluarkan pada usahatani sayur tumpangsari akan dapat diketahui keuntungan masing-masing sayur pada setiap model tumpangsari. Keuntungan merupakan selisih antara penerimaan dengan biaya yang dikeluarkan oleh petani sehingga akan diperoleh keuntungan masing-masing sayur tumpangsari. Nilai keuntungan setiap sayur yang diperoleh dapat digunakan untuk menghitung keuntungan setiap model tumpangsari. Keuntungan pada setiap model tumpangsari dapat dirumuskan kedalam model fungsi tujuan untuk mengetahui keuntungan maksimal yang diperoleh. Keuntungan usahatani sayur pada model tumpangsari 1 dapat dilihat pada Tabel 5.

Tabel 5. Keuntungan Sayur Model Tumpangsari 1 dalam Satu Kali Tanam Luasan Lahan Setiap Sayur 1 Ha Pada Musim Kemarau Tahun 2019

\begin{tabular}{clcccc}
\hline $\begin{array}{c}\text { Model } \\
\text { Tumpangsari }\end{array}$ & $\begin{array}{c}\text { Jenis } \\
\text { Sayur }\end{array}$ & $\begin{array}{c}\text { Penerimaan } \\
(\mathrm{Rp})\end{array}$ & $\begin{array}{c}\text { Total Biaya } \\
(\mathrm{Rp})\end{array}$ & $\begin{array}{c}\text { Keuntungan } \\
(\mathrm{Rp})\end{array}$ & $\begin{array}{c}\text { Total } \\
\text { Keuntungan } \\
(\mathrm{Rp})\end{array}$ \\
\hline Tumpangsari 1 & Sawi & 287.722 .222 & 197.384 .175 & 90.338 .047 & 264.008 .323 \\
& Bayam & 305.416 .667 & 131.746 .391 & 173.670 .276 & \\
\hline
\end{tabular}

Sumber : Data Primer diolah (2019)

Berdasarkan Tabel 5 dapat diketahui keuntungan usahatani sayur pada model tumpangsari 1 sebesar Rp264.008.323. Jenis sayur yang memperoleh keuntungan terbesar adalah sayur bayam sebesar Rp173.670.276 dan jenis sayur yang memperoleh keuntungan terendah adalah sayur sawi sebesar Rp90.338.047. Sayur bayam memperoleh keuntungan terbesar dikarenakan total biaya yang dikeluarkan lebih rendah dari sayur sawi dan memiliki 
penerimaan yang lebih besar dari sayur sawi. Keuntungan usahatani sayur pada model tumpangsari 2 dapat dilihat pada Tabel 6.

Tabel 6. Keuntungan Sayur Model Tumpangsari 2 dalam Satu Kali Tanam Luasan Lahan Setiap Sayur 1 Ha Pada Musim Kemarau Tahun 2019

\begin{tabular}{clcccc}
\hline $\begin{array}{c}\text { Model } \\
\text { Tumpangsari }\end{array}$ & \multicolumn{1}{c}{$\begin{array}{c}\text { Jenis } \\
\text { Sayur }\end{array}$} & $\begin{array}{c}\text { Penerimaan } \\
(\mathrm{Rp})\end{array}$ & $\begin{array}{c}\text { Total Biaya } \\
(\mathrm{Rp})\end{array}$ & $\begin{array}{c}\text { Keuntungan } \\
(\mathrm{Rp})\end{array}$ & $\begin{array}{c}\text { Total } \\
\text { Keuntungan } \\
(\mathrm{Rp})\end{array}$ \\
\hline Tumpangsari 2 & Sawi & 269.166 .667 & 150.650 .489 & 118.516 .177 & 380.718 .710 \\
& Bayam & 295.833 .333 & 109.786 .910 & 186.046 .424 & \\
& Kangkung & 185.350 .000 & 109.193 .891 & 76.156 .109 & \\
\hline
\end{tabular}

Sumber : Data Primer diolah (2019)

Keuntungan usahatani sayur pada model tumpangsari 2 sebesar Rp380.718.710. Jenis sayur yang memperoleh keuntungan terbesar adalah sayur bayam sebesar Rp186.046.424 dan jenis sayur yang memperoleh keuntungan terendah adalah sayur kangkung sebesar Rp76.156.109. Sayur bayam memperoleh keuntungan terbesar dikarenakan penerimaan sayur bayam lebih besar dari sayur lainnya dan mengeluarkan biaya yang rendah untuk kegiatan usahatani sayur bayam. Sayur kangkung memperoleh keuntungan yang paling rendah dikarenakan selisih antara penerimaan dan biaya yang dikeluarkan tidak besar. Keuntungan usahatani sayur pada model tumpangsari 3 dapat dilihat pada Tabel 7.

Tabel 7. Keuntungan Sayur Model Tumpangsari 3 dalam Satu Kali Tanam Luasan Lahan Setiap Sayur 1 Ha Pada Musim Kemarau Tahun 2019

\begin{tabular}{clcccc}
\hline $\begin{array}{c}\text { Model } \\
\text { Tumpangsari }\end{array}$ & \multicolumn{1}{c}{$\begin{array}{c}\text { Jenis } \\
\text { Sayur }\end{array}$} & $\begin{array}{c}\text { Penerimaan } \\
(\mathrm{Rp})\end{array}$ & $\begin{array}{c}\text { Total Biaya } \\
(\mathrm{Rp})\end{array}$ & $\begin{array}{c}\text { Keuntungan } \\
(\mathrm{Rp})\end{array}$ & $\begin{array}{c}\text { Total } \\
\text { Keuntungan } \\
(\mathrm{Rp})\end{array}$ \\
\hline Tumpangsari 3 & Sawi & 280.815 .972 & 142.199 .703 & 138.616 .270 & 654.014 .908 \\
& Kangkung & 204.875 .000 & 98.927 .824 & 105.947 .176 & \\
& Bayam & 312.500 .000 & 90.695 .773 & 221.804 .227 & \\
& Kemangi & 326.400 .000 & 138.752 .765 & 187.647 .235 & \\
\hline
\end{tabular}

Sumber : Data Primer diolah (2019)

Keuntungan usahatani sayur pada model tumpangsari 3 sebesar Rp654.014.908. Jenis sayur yang memperoleh keuntungan terbesar adalah sayur bayam sebesar Rp221.804.227 dan jenis sayur yang memperoleh keuntungan terendah adalah sayur kangkung sebesar Rp105.947.176. Penerimaan usahatani sayur bayam lebih rendah dari penerimaan usahatani sayur kemangi, tetapi sayur bayam memiliki keuntungan yang lebih tinggi dari sayur kemangi. Hal tersebut disebabkan oleh biaya usahatani sayur bayam yang lebih rendah dari sayur kemangi. Sayur kangkung mendapatkan keuntungan yang paling rendah dikarenakan penerimaan yang diperoleh sayur kangkung lebih rendah dibandingkan dengan sayur lainnya. Keuntungan usahatani sayur pada model tumpangsari 4 dapat dilihat pada Tabel 8.

Keuntungan usahatani sayur model tumpangsari 4 sebesar Rp583.231.708. Jenis sayur yang memperoleh keuntungan terbesar adalah sayur bayam sebesar Rp189.209.410 dan jenis sayur yang memperoleh keuntungan terendah adalah sayur kenikir sebesar Rp50.233.304. Biaya usahatani sayur bayam yang lebih rendah dari sayur kemangi menyebabkan usahatani sayur bayam memperoleh keuntungan terbesar meskipun penerimaan usahatani sayur bayam lebih rendah dari usahatani sayur kemangi. Sayur kenikir memperoleh keuntungan yang paling rendah dikarenakan penerimaan sayur kenikir lebih rendah dibandingkan dengan penerimaan sayur lainnya pada model tumpangsari 4. 
Tabel 8. Keuntungan Sayur Model Tumpangsari 4 dalam Satu Kali Tanam Luasan Lahan Setiap Sayur 1 Ha Pada Musim Kemarau Tahun 2019

\begin{tabular}{|c|c|c|c|c|c|}
\hline $\begin{array}{c}\text { Model } \\
\text { Tumpangsari }\end{array}$ & $\begin{array}{l}\text { Jenis } \\
\text { Sayur }\end{array}$ & $\begin{array}{c}\text { Penerimaan } \\
(\mathrm{Rp})\end{array}$ & $\begin{array}{c}\text { Total Biaya } \\
\text { (Rp) }\end{array}$ & $\begin{array}{l}\text { Keuntungan } \\
(\mathrm{Rp})\end{array}$ & $\begin{array}{c}\text { Total } \\
\text { Keuntungan (Rp) }\end{array}$ \\
\hline \multirow[t]{5}{*}{ Tumpangsari 4} & Bayam & 300.416 .667 & 111.207 .256 & 189.209 .410 & 583.231 .708 \\
\hline & Sawi & 290.567 .178 & 170.163 .821 & 120.403 .357 & \\
\hline & Kangkung & 194.975 .000 & 118.867 .871 & 76.107 .129 & \\
\hline & Kenikir & 135.691 .111 & 85.457 .807 & 50.233 .304 & \\
\hline & Kemangi & 338.300 .000 & 191.021 .493 & 147.278 .507 & \\
\hline
\end{tabular}

Sumber : Data Primer diolah (2019)

Berdasarkan perolehan keuntungan setiap sayur dan keuntungan setiap model tumpangsari dapat dirumuskan model matematis fungsi tujuan. Berikut merupakan model matematis fungsi tujuan setiap model tumpangsari.

1. Model Tumpangsari 1:

$$
\mathrm{Z}=\text { 90.338.047 } \mathrm{X}_{1}+173.670 .276 \mathrm{X}_{2}
$$

2. Model Tumpangsari 2:

$$
Z=118.516 .177 X_{1}+186.046 .424 X_{2}+76.156 .109 X_{3}
$$

3. Model Tumpangsari 3:

$$
Z=138.616 .270 X_{1}+105.947 .176 X_{2}+221.804 .227 X_{3}+187.647 .235 X_{4}
$$

4. Model Tumpangsari 4:

$$
Z=\begin{aligned}
& 189.209 .410 X_{1}+120.403 .357 X_{2}+76.107 .129 X_{3}+50.233 .304 X_{4}+147.278 .507 \\
& X_{5}
\end{aligned}
$$

Kondisi keuntungan maksimal setiap model tumpangsari adalah kombinasi sayuran yang harus ditanam oleh petani untuk memperoleh keuntungan maksimal dengan keterbatasan faktor produksi yang ada. Kondisi keuntungan maksimal setiap model tumpangsari dapat dilihat dari nilai reduced cost dan value pada hasil analisis. Tanaman sayur yang memiliki nilai reduced cost sama dengan 0 merupakan sayur yang harus ditanam oleh petani, sedangkan tanaman sayur yang nilai reduced cost nya tidak sama dengan nol merupakan sayur yang tidak ditanam oleh petani. Tanaman sayur yang nilai reduced cost lebih besar dari 0 tersebut jika ditanam maka akan mengurangi keuntungan usahatani sayur tumpangsari sebesar nilai reduced cost nya. Berdasarkan hasil analisis juga dapat diketahui jumlah luasan lahan yang digunakan untuk penanaman setiap jenis sayur dalam satu kali tanam. Jumlah luasan lahan tersebut diperoleh dari hasil perkalian antara value dengan luas lahan sayur yang digunakan dalam satu kali tanam pada kondisi aktual. Besaran luas lahan dan kombinasi sayur model tumpangsari 1 yang dapat memberikan keuntungan maksimal dapat dilihat pada Tabel 9.

Tabel 9. Kombinasi Sayur Model Tumpangsari 1 yang dapat Memberikan Keuntungan Maksimal dalam Satu Kali Tanam Pada Musim Kemarau Tahun 2019

\begin{tabular}{clrr}
\hline \multirow{2}{*}{ No } & Sayur yang ditanam & $\begin{array}{r}\text { Luas Lahan yang digunakan } \\
\left(\mathrm{m}^{2}\right)\end{array}$ & Keuntungan Maksimal (Rp) \\
\hline 1 & Sawi & 5.707 & 51.555 .923 \\
2 & Bayam & 14.293 & 248.226 .925 \\
\hline & Total & 20.000 & 299.782 .848 \\
\hline
\end{tabular}

Sumber : Data Primer diolah (2019) 
Berdasarkan Tabel 9 dapat diketahui bahwa keuntungan maksimal model tumpangsari 1 dapat diperoleh dengan menanam sayur sawi dan sayur bayam. Besaran luas lahan yang digunakan pada sayur sawi dan sayur bayam pada kondisi keuntungan maksimal diperoleh dari hasil perkalian antara value pada hasil analisis dengan luas lahan sayur sawi dan sayur bayam yang digunakan dalam satu kali tanam. Value pada sayur sawi sebesar 0,5707 dan value pada sayur bayam sebesar 1,4293 dalam 1 kali tanam. Luas lahan sayur sawi yang digunakan pada model tumpangsari 1 sebesar $10.000 \mathrm{~m}^{2}$ dan sayur bayam sebesar $10.000 \mathrm{~m}^{2}$ untuk satu kali tanam pada kondisi aktual. Luasan lahan yang digunakan pada masing-masing sayur dalam satu kali tanam untuk memperoleh keuntungan maksimal adalah dengan menanam sayur sawi pada luas lahan sebesar $5.707 \mathrm{~m}^{2}$ dan menanam sayur bayam pada luas lahan sebesar $14.293 \mathrm{~m}^{2}$. Keuntungan maksimal usahatani sayur model tumpangsari 1 dalam satu kali tanam dapat diperoleh dari perhitungan berikut.

$$
\begin{aligned}
\mathrm{Z} & =90.338 .047 \mathrm{X}_{1}+173.670 .276 \mathrm{X}_{2} \\
& =(90.338 .047 \times 0,5707)+(173.670 .276 \times 1,4293) \\
& =51.555 .923+248.226 .925 \\
& =299.782 .848
\end{aligned}
$$

Keuntungan maksimal yang diperoleh pada model tumpangsari 1 sebesar Rp299.782.848. Nilai keuntungan maksimal tersebut diperoleh dari hasil kali antara keuntungan pada kondisi aktual dalam satu kali tanam dengan value pada hasil analisis keuntungan maksimal. Jenis sayur yang memperoleh keuntungan tertinggi pada model tumpangsari 1 adalah sayur bayam sebesar Rp248.226.925 dan jenis sayur yang memperoleh keuntungan terendah adalah sayur sawi sebesar Rp51.555.923. Usahatani sayur bayam pada kondisi keuntungan maksimal memiliki keuntungan tertinggi disebabkan oleh luas lahan yang digunakan pada kondisi keuntungan maksimal jauh lebih besar dibandingkan dengan luas lahan sayur sawi. Luas lahan pada usahatani sayur bayam digunakan secara maksimal melebihi luas lahan yang digunakan pada kondisi keuntungan aktual. Besaran luas lahan dan kombinasi sayur model tumpangsari 2 yang dapat memberikan keuntungan maksimal dapat dilihat pada Tabel 10.

Tabel 10. Kombinasi Sayur Model Tumpangsari 2 yang dapat Memberikan Keuntungan Maksimal dalam Satu Kali Tanam Pada Musim Kemarau Tahun 2019

\begin{tabular}{clrr}
\hline \multirow{2}{*}{ No } & \multirow{2}{*}{ Sayur yang ditanam } & $\begin{array}{r}\text { Luas Lahan yang digunakan } \\
\left(\mathrm{m}^{2}\right)\end{array}$ & Keuntungan Maksimal (Rp) \\
\hline 1 & Sawi & 10.915 & 129.360 .408 \\
2 & Bayam & 14.282 & 265.711 .502 \\
3 & Kangkung & 4.620 & 35.184 .122 \\
\hline & Total & 29.817 & 430.256 .032 \\
\hline
\end{tabular}

Sumber : Data Primer diolah (2019)

Berdasarkan Tabel 10 dapat diketahui bahwa keuntungan maksimal model tumpangsari 2 dapat diperoleh dengan menanam sayur sawi, sayur bayam dan sayur kangkung. Besaran luas lahan yang digunakan pada sayur sawi, sayur bayam dan sayur kangkung pada kondisi keuntungan maksimal diperoleh dari hasil perkalian antara value pada hasil analisis dengan luas lahan sayur sawi, sayur bayam dan sayur kangkung yang digunakan dalam satu kali tanam. Value pada sayur sawi sebesar 1,0915, sayur bayam sebesar 1,4282 dan sayur kangkung sebesar 0,462 dalam 1 kali tanam. Luas lahan sayur sawi yang digunakan dalam satu kali tanam sebesar $10.000 \mathrm{~m}^{2}$ pada kondisi aktual sehingga untuk memperoleh keuntungan maksimal, luas lahan yang ditanam sayur sawi sebesar $10.915 \mathrm{~m}^{2}$ dalam $1 \mathrm{kali}$ 
tanam. Luas lahan sayur bayam yang digunakan dalam satu kali tanam sebesar $10.000 \mathrm{~m}^{2}$ pada kondisi aktual dan untuk memperoleh keuntungan maksimal, luas lahan yang ditanam sayur bayam sebesar $14.282 \mathrm{~m}^{2}$ dalam 1 kali tanam. Luas lahan sayur kangkung yang digunakan pada model tumpangsari 2 dalam satu kali tanam sebesar $10.000 \mathrm{~m}^{2}$ pada kondisi aktual dan untuk memperoleh keuntungan maksimal, luas lahan yang harus ditanami sayur kangkung sebesar $4.620 \mathrm{~m}^{2}$ dalam satu kali tanam. Keuntungan maksimal model tumpangsari 2 dalam satu kali tanam dapat diperoleh dari perhitungan berikut.

$$
\begin{aligned}
\mathrm{Z} & =118.516 .177 \mathrm{X}_{1}+186.046 .424 \mathrm{X}_{2}+76.156 .109 \mathrm{X}_{3} \\
& =(118.516 .177 \times 1,0915)+(186.046 .424 \times 1,4282)+(76.156 .109 \times 0,462) \\
& =129.360 .408+265.711 .502+35.184 .122 \\
& =430.256 .032
\end{aligned}
$$

Keuntungan maksimal yang diperoleh pada model tumpangsari 2 sebesar Rp430.256.032. Nilai keuntungan maksimal tersebut diperoleh dari hasil kali antara keuntungan pada kondisi aktual dalam satu kali tanam dengan value pada hasil analisis keuntungan maksimal. Jenis sayur yang memperoleh keuntungan tertinggi pada model tumpangsari 2 adalah sayur bayam sebesar Rp265.711.502 dan jenis sayur yang memperoleh keuntungan terendah adalah sayur kangkung sebesar Rp35.184.122. Usahatani sayur bayam pada kondisi keuntungan maksimal memperoleh keuntungan tertinggi disebabkan oleh luas lahan yang digunakan lebih besar dibandingkan dengan luas lahan sayur sawi dan luas lahan sayur kangkung. Luas lahan pada usahatani sayur bayam digunakan secara maksimal melebihi luas lahan yang digunakan pada kondisi keuntungan aktual. Usahatani sayur kangkung pada kondisi keuntungan maksimal memperoleh keuntungan terendah dikarenakan pada hasil analisis, luas lahan sayur kangkung tidak digunakan secara maksimal atau penggunaan luas lahannya lebih rendah dari luas lahan yang digunakan pada kondisi keuntungan aktual. Besaran luas lahan dan kombinasi sayur model tumpangsari 3 yang dapat memberikan keuntungan maksimal dapat dilihat pada Tabel 11.

Tabel 11. Kombinasi Sayur Model Tumpangsari 3 yang dapat Memberikan Keuntungan Maksimal dalam Satu Kali Tanam Pada Musim Kemarau Tahun 2019

\begin{tabular}{clrr}
\hline \multirow{2}{*}{ No } & Sayur yang ditanam & $\begin{array}{c}\text { Luas Lahan yang digunakan } \\
\left(\mathrm{m}^{2}\right)\end{array}$ & Keuntungan Maksimal (Rp) \\
\hline 1 & Sawi & 10.720 & 148.596 .641 \\
2 & Bayam & 14.418 & 319.797 .334 \\
3 & Kemangi & 13.849 & 259.872 .656 \\
\hline & Total & 38.987 & 728.266 .632 \\
\hline
\end{tabular}

Sumber : Data Primer diolah (2019)

Berdasarkan Tabel 11 dapat diketahui bahwa keuntungan maksimal model tumpangsari 3 dapat diperoleh dengan menanam sayur sawi, sayur bayam dan sayur kemangi. Sayur kangkung tidak ditanam pada kondisi keuntungan maksimal dikarenakan memiliki nilai reduced cost yang lebih besar dari 0 sehingga apabila sayur kangkung ditanam akan menyebabkan keuntungan usahatani pada model tumpangsari 3 akan berkurang sebesar nilai reduced cost yang dihasilkan. Besaran luas lahan yang digunakan pada sayur sawi, sayur bayam dan sayur kemangi pada kondisi keuntungan maksimal diperoleh dari hasil perkalian antara value dengan luas lahan sayur sawi, sayur bayam dan sayur kemangi yang digunakan dalam satu kali tanam. Value pada sayur sawi sebesar 1,072, sayur bayam sebesar 1,4418 dan sayur kemangi sebesar 1,3849 dalam 1 kali tanam. Luas lahan sayur sawi yang digunakan untuk satu kali tanam sebesar $10.000 \mathrm{~m}^{2}$ pada kondisi aktual dan berdasarkan hasil analisis 
untuk memperoleh keuntungan maksimal, luas lahan yang digunakan untuk menanam sayur sawi sebesar $10.720 \mathrm{~m}^{2}$ dalam $1 \mathrm{kali}$ tanam. Luas lahan yang digunakan untuk menanam sayur bayam dalam satu kali tanam sebesar $10.000 \mathrm{~m}^{2}$ pada kondisi aktual dan untuk memperoleh keuntungan maksimal, luas lahan yang digunakan untuk menanam sayur bayam sebesar $14.418 \mathrm{~m}^{2}$ dalam satu kali tanam. Luas lahan sayur kemangi dalam satu kali tanam sebesar $10.000 \mathrm{~m}^{2}$ pada kondisi aktual. Berdasarkan hasil analisis pada kondisi keuntungan maksimal, luas lahan yang digunakan untuk menanam sayur kemangi sebesar $13.849 \mathrm{~m}^{2}$ dalam satu kali tanam untuk memperoleh keuntungan maksimal. Keuntungan maksimal model tumpangsari 3 dalam satu kali tanam dapat diperoleh dari perhitungan berikut.

$$
\begin{aligned}
\mathrm{Z} & =138.616 .270 \mathrm{X}_{1}+105.947 .176 \mathrm{X}_{2}+221.804 .227 \mathrm{X}_{3}+187.647 .235 \mathrm{X}_{4} \\
& =(138.616 .270 \times 1,072)+(105.947 .176 \times 0)+(221.804 .227 \times 1,4418)+(187.647 .235 \mathrm{x} \\
& 1,3849) \\
= & 148.596 .641+0+319.797 .334+259.872 .656 \\
= & 728.266 .632
\end{aligned}
$$

Keuntungan maksimal yang diperoleh pada model tumpangsari 3 sebesar Rp728.266.632. Nilai keuntungan maksimal tersebut diperoleh dari hasil kali antara keuntungan pada kondisi aktual dalam satu kali tanam dengan value pada hasil analisis keuntungan maksimal. Jenis sayur yang memperoleh keuntungan tertinggi pada model tumpangsari 3 adalah sayur bayam sebesar Rp319.797.334 dan jenis sayur yang memperoleh keuntungan terendah adalah sayur sawi sebesar Rp148.596.641. Usahatani sayur bayam pada kondisi keuntungan maksimal memperoleh keuntungan tertinggi disebabkan oleh luas lahan yang digunakan lebih besar dibandingkan dengan luas lahan sayur sawi dan kemangi. Usahatani sayur sawi pada kondisi maksimal memperoleh keuntungan terendah disebabkan oleh luas lahan yang digunakan lebih kecil dibandingkan dengan luas lahan sayur bayam dan kemangi. Besaran luas lahan dan kombinasi sayur model tumpangsari 4 yang dapat memberikan keuntungan maksimal dapat dilihat pada Tabel 12.

Tabel 12. Kombinasi Sayur Model Tumpangsari 4 yang dapat Memberikan Keuntungan Maksimal dalam Satu Kali Tanam Pada Musim Kemarau Tahun 2019

\begin{tabular}{clrr}
\hline \multirow{2}{*}{ No } & Sayur yang ditanam & $\begin{array}{r}\text { Luas Lahan yang digunakan } \\
\left(\mathrm{m}^{2}\right)\end{array}$ & Keuntungan Maksimal (Rp) \\
\hline 1 & Bayam & 14.337 & 271.269 .532 \\
2 & Sawi & 13.110 & 157.848 .801 \\
4 & Kenikir & 6.586 & 33.083 .654 \\
5 & Kemangi & 14.450 & 212.817 .443 \\
\hline & Total & 48.483 & 675.019 .430 \\
\hline
\end{tabular}

Sumber : Data Primer diolah (2019)

Berdasarkan Tabel 12 dapat diketahui bahwa keuntungan maksimal model tumpangsari 4 dapat diperoleh dengan menanam sayur bayam, sayur sawi, sayur kenikir dan sayur kemangi. Besaran luas lahan yang digunakan pada sayur bayam, sayur sawi, sayur kenikir dan sayur kemangi pada kondisi keuntungan maksimal diperoleh dari hasil perkalian antara value dengan luas lahan sayur bayam, sayur sawi, sayur kenikir dan sayur kemangi yang digunakan dalam satu kali tanam. Value pada sayur bayam sebesar 1,4337, sayur sawi sebesar 1,311, sayur kenikir sebesar 0,6586 dan sayur kemangi sebesar 1,445 dalam satu kali tanam untuk memperoleh keuntungan maksimal. Luas lahan sayur bayam, sayur sawi, sayur kenikir dan sayur kemangi yang digunakan dalam satu kali tanam pada kondisi aktual adalah sebesar $10.000 \mathrm{~m}^{2}$ untuk masing-masing sayur. Luasan lahan yang digunakan pada masing- 
masing sayur dalam satu kali tanam untuk memperoleh keuntungan maksimal adalah dengan menanam sayur bayam pada luasan lahan sebesar $14.337 \mathrm{~m}^{2}$, sayur sawi pada luasan lahan sebesar $13.110 \mathrm{~m}^{2}$, sayur kenikir pada luasan lahan sebesar $6.586 \mathrm{~m}^{2}$ dan sayur kemangi pada luasan lahan sebesar $14.450 \mathrm{~m}^{2}$. Keuntungan maksimal model tumpangsari 4 dalam satu kali tanam dapat diperoleh dari perhitungan berikut.

$$
\begin{aligned}
Z= & 189.209 .410 X_{1}+120.403 .357 X_{2}+76.107 .129 X_{3}+50.233 .304 X_{4}+147.278 .507 X_{5} \\
= & (189.209 .410 \times 1,4337)+(120.403 .357 \times 1,311)+(76.107 .129 \times 0)+(50.233 .304 \times \\
& 0,6586)+(147.278 .507 \times 1,445) \\
= & 271.269 .532+157.848 .801+0+33.083 .654+212.817 .443 \\
= & 675.019 .430
\end{aligned}
$$

Keuntungan maksimal yang diperoleh pada model tumpangsari 4 sebesar Rp675.019.430. Nilai keuntungan maksimal tersebut diperoleh dari hasil kali antara keuntungan pada kondisi aktual dalam satu kali tanam dengan value pada hasil analisis keuntungan maksimal. Jenis sayur yang memperoleh keuntungan tertinggi pada model tumpangsari 4 adalah sayur bayam sebesar Rp271.269.532 dan jenis sayur yang memperoleh keuntungan terendah adalah sayur kenikir sebesar Rp33.083.654. Luas lahan yang digunakan pada usahatani sayur bayam dalam kondisi keuntungan maksimal lebih kecil jika dibandingkan dengan luas lahan sayur kemangi, tetapi keuntungan yang diperoleh sayur bayam dalam kondisi keuntungan maksimal lebih besar. Hal tersebut dikarenakan keuntungan usahatani sayur bayam yang dirumuskan dalam model fungsi tujuan sebelum dilakukan analisis lebih besar jika dibandingkan dengan sayur kemangi sehingga dapat menyebabkan keuntungan sayur bayam lebih besar ketika telah dilakukan analisis pada kondisi keuntungan maksimal. Usahatani sayur kenikir pada kondisi keuntungan maksimal memperoleh keuntungan rendah dikarenakan pada hasil analisis, luas lahan sayur kenikir tidak digunakan secara maksimal atau penggunaan luas lahannya lebih rendah dari luas lahan yang digunakan pada kondisi keuntungan aktual dan luas lahan sayur kenikir pada kondisi keuntungan maksimal lebih rendah dibandingkan luas lahan sayur lainnya pada model tumpangsari 4.

Berdasarkan hasil analisis kombinasi usahatani sayur pada masing-masing model tumpangsari, untuk memperoleh keuntungan maksimal terdapat model tumpangsari yang menanam semua jenis sayuran dan terdapat model tumpangsari yang tidak menanam semua jenis sayuran atau mengalami pengurangan jumlah sayuran dari jumlah sayuran yang ditanam pada kondisi aktual. Hasil analisis tersebut sesuai dengan penelitian yang dilakukan oleh Djafri et al (2017) yang menjelaskan bahwa kondisi optimal tidak mengharuskan semua sayuran mengalami peningkatan produksi namun juga dapat terjadi pengurangan produksi atau dalam kondisi optimal tidak mengharuskan memproduksi semua jenis sayuran. Hal tersebut disebabkan pengaruh efisiensi sumberdaya setiap tanaman berbeda dan potensi keuntungannya juga berbeda.

Penggunaan faktor produksi digunakan untuk mengetahui hubungan antara usahatani sayur tumpangsari dengan keterbatasan faktor produksi usahatani yang dimiliki untuk memperoleh keuntungan maksimal dalam satu kali tanam. Kondisi tersebut dapat dilihat dari nilai slack/surplus pada hasil analisis. Nilai slack/surplus sebesar nol menunjukkan bahwa faktor produksi pada usahatani sayur tumpangsari habis terpakai atau langka. Nilai slack/surplus lebih besar dari nol menunjukkan bahwa faktor produksi pada usahatani sayur tumpangsari memiliki jumlah yang berlebih. Faktor produksi langka akan memiliki dual value yang lebih besar dari nol. Dual value tertinggi menjadi keterbatasan utama untuk mencapai keuntungan maksimal pada usahatani sayur tumpangsari. Faktor produksi yang memiliki dual value lebih besar dari nol akan memberikan tambahan keuntungan sebesar 
nilai dual value tersebut jika ketersediaannya ditambah satu satuan. Faktor produksi langka pada model tumpangsari 1 dapat dilihat pada Tabel 13.

Tabel 13. Faktor produksi Langka pada Usahatani Sayur Model Tumpangsari 1 dalam Satu Kali Tanam Pada Musim Kemarau Tahun 2019

\begin{tabular}{clrr}
\hline No & Faktor Produksi & Dual Value & Slack /surplus \\
\hline 1 & Lahan Bayam $\left(\mathrm{m}^{2}\right)$ & $8.333,226$ & 0 \\
2 & Pupuk ZA $(\mathrm{Kg})$ & $90.338,05$ & 0 \\
\hline
\end{tabular}

Sumber : Data Primer diolah (2019)

Berdasarkan Tabel 13 dapat diketahui bahwa pada model tumpangsari 1 yang menjadi faktor produksi langka adalah lahan bayam dan pupuk ZA. Keterbatasan utama untuk mencapai keuntungan maksimal pada model tumpangsari 1 adalah faktor produksi pupuk ZA karena memiliki dual value yang lebih besar dari lahan bayam. Lahan bayam menjadi faktor produksi langka dikarenakan sayur bayam memiliki keuntungan yang paling besar diantara semua sayur pada model tumpangsari 1 dalam kondisi keuntungan maksimal sehingga lahan yang tersedia untuk sayur bayam digunakan seluruhnya. Pupuk ZA menjadi faktor produksi langka dikarenakan semua sayur membutuhkan pupuk ZA untuk kegiatan pemupukan, sementara pupuk ZA yang tersedia jumlahnya tidak berlebih sehingga pupuk ZA yang tersedia tersebut digunakan seluruhnya untuk mencapai keuntungan maksimal. Dual value pada lahan bayam menunjukkan bahwa penambahan $1 \mathrm{~m}^{2}$ lahan bayam akan meningkatkan keuntungan sebesar Rp8.333 dan besaran dual value pada pupuk ZA menunjukkan bahwa penambahan $1 \mathrm{Kg}$ pupuk ZA akan menambah keuntungan petani sebesar Rp90.388 pada kondisi keuntungan maksimal. Faktor produksi langka pada model tumpangsari 2 dapat dilihat pada Tabel 14 .

Tabel 14. Faktor produksi Langka pada Usahatani Sayur Model Tumpangsari 2 dalam Satu Kali Tanam Pada Musim Kemarau Tahun 2019

\begin{tabular}{clrr}
\hline No & Faktor Produksi & Dual Value & Slack /surplus \\
\hline 1 & Lahan Bayam $\left(\mathrm{m}^{2}\right)$ & $11.294,61$ & 0 \\
2 & Pupuk Kandang $(\mathrm{Kg})$ & 563,7595 & 0 \\
3 & Pestisida Callicron $(\mathrm{ml})$ & $20.591,46$ & 0 \\
\hline
\end{tabular}

Sumber : Data Primer diolah (2019)

Berdasarkan Tabel 14 dapat diketahui bahwa pada model tumpangsari 2 terdapat tiga faktor produksi yang termasuk faktor produksi langka yaitu lahan bayam, pupuk kandang dan pestisida callicron. Keterbatasan utama untuk mencapai keuntungan maksimal pada model tumpangsari 2 adalah pestisida callicron karena memiliki dual value terbesar diantara faktor produksi lainnya. Lahan sayur bayam merupakan faktor produksi langka dikarenakan sayur bayam memiliki keuntungan yang paling besar diantara semua sayur pada model tumpangsari 1 dalam kondisi keuntungan maksimal sehingga lahan yang tersedia untuk sayur bayam digunakan seluruhnya. Pupuk kandang termasuk faktor produksi langka dikarenakan semua sayur membutuhkan pupuk kandang untuk kegiatan pemupukan sementara pupuk kandang yang tersedia jumlahnya sedikit atau tidak berlebih sehingga pupuk kandang yang tersedia digunakan seluruhnya. Pestisida callicron merupakan faktor produksi langka dikarenakan ketersediaan pestisida callicron tidak berlebih sehingga digunakan seluruhnya untuk mencapai keuntungan maksimal. Nilai dual pada lahan bayam menunjukkan bahwa penambahan $1 \mathrm{~m}^{2}$ lahan bayam akan meningkatkan keuntungan petani sebesar Rp11.295. Besaran dual value pada pupuk kandang menunjukkan bahwa setiap penambahan pupuk kandang sebesar $1 \mathrm{Kg}$ akan menambah keuntungan petani sebesar Rp564 dan dual value pada 
pestisida callicron menunjukkan bahwa setiap penambahan $1 \mathrm{ml}$ akan meningkatkan keuntungan petani sebesar Rp20.591. Faktor produksi langka pada model tumpangsari 3 dapat dilihat pada Tabel 15 .

Tabel 15. Faktor produksi Langka pada Usahatani Sayur Model Tumpangsari 3 dalam Satu Kali Tanam Pada Musim Kemarau Tahun 2019

\begin{tabular}{|c|c|c|c|c|}
\hline No & Faktor Produksi & & Dual Value & Slack/surplus \\
\hline 1 & Lahan Bayam $\left(\mathrm{m}^{2}\right)$ & & $8.449,758$ & 0 \\
\hline 2 & Pupuk Kandang (Kg) & & 255,6666 & 0 \\
\hline 3 & $\begin{array}{l}\text { Pestisida Amnistar } \\
(\mathrm{ml})\end{array}$ & Top & $101.702,0$ & 0 \\
\hline
\end{tabular}

Sumber : Data Primer diolah (2019)

Berdasarkan Tabel 15 dapat diketahui bahwa pada model tumpangsari 3 terdapat tiga faktor produksi langka yaitu lahan bayam, pupuk kandang dan pestisida amnistar top. Keterbatasan utama untuk mencapai keuntungan maksimal pada model tumpangsari 3 adalah pestisida amnistar top karena memiliki dual value terbesar diantara faktor produksi lainnya. Faktor produksi lahan bayam menjadi faktor produksi langka dikarenakan memperoleh keuntungan yang lebih besar dibandingkan sayur lainnya pada model tumpangsari 3 dalam kondisi keuntungan maksimal sehingga lahan bayam digunakan seluruhnya untuk mencapai keuntungan maksimal. Pupuk kandang dan pestisida amnistar top termasuk faktor produksi langka dikarenakan semua sayur membutuhkan pupuk kandang dan pestisida amnistar top untuk kegiatan budidaya sementara pupuk kandang dan pestisida amnistar top yang tersedia jumlahnya sedikit atau tidak berlebih sehingga pupuk kandang dan pestisida amnistar top yang tersedia digunakan seluruhnya pada kondisi keuntungan maksimal. Faktor produksi lahan bayam memiliki dual value dimana nilai tersebut menunjukkan bahwa setiap penambahan $1 \mathrm{~m}^{2}$ luas lahan bayam akan meningkatkan keuntungan petani sebesar Rp8.449. Tambahan pupuk kandang sebesar $1 \mathrm{Kg}$ akan menambah keuntungan petani sebesar Rp256 pada kondisi keuntungan maksimal. Tambahan pestisida amnistar top sebesar $1 \mathrm{ml}$ akan menambah keuntungan petani sebesar Rp101.702 pada kondisi keuntungan maksimal. Faktor produksi langka pada model tumpangsari 4 dapat dilihat pada Tabel 16.

Tabel 16. Faktor produksi Langka pada Usahatani Sayur Model Tumpangsari 4 dalam Satu Kali Tanam Pada Musim Kemarau Tahun 2019

\begin{tabular}{clrr}
\hline No & Faktor Produksi & Dual Value & Slack/ surplus \\
\hline 1 & Lahan Bayam $\left(\mathrm{m}^{2}\right)$ & $11.655,31$ & 0 \\
2 & Lahan Kemangi $\left(\mathrm{m}^{2}\right)$ & $8.694,236$ & 0 \\
3 & Pupuk Kandang $(\mathrm{Kg})$ & 505,1416 & 0 \\
4 & Pestisida Callicron $(\mathrm{ml})$ & $31.684,39$ & 0 \\
\hline
\end{tabular}

Sumber : Data Primer diolah (2019)

Faktor produksi langka pada model tumpangsari 4 adalah lahan bayam, lahan kemangi, pupuk kandang dan pestisida callicron. Keterbatasan utama untuk mencapai keuntungan maksimal pada model tumpangsari 4 adalah pestisida callicron karena memiliki dual value terbesar diantara faktor produksi lainnya. Faktor produksi lahan bayam dan lahan kemangi menjadi faktor produksi langka dikarenakan memperoleh keuntungan yang lebih besar dibandingkan sayur lainnya pada model tumpangsari 4 dalam kondisi keuntungan maksimal sehingga lahan bayam dan lahan kemangi digunakan seluruhnya untuk mencapai keuntungan maksimal. Pupuk kandang termasuk faktor produksi langka dikarenakan semua sayur membutuhkan pupuk kandang untuk kegiatan pemupukan sementara pupuk kandang 
yang tersedia jumlahnya sedikit atau tidak berlebih sehingga pupuk kandang yang tersedia digunakan seluruhnya. Pestisida callicron merupakan faktor produksi langka dikarenakan ketersediaan pestisida callicron tidak berlebih sehingga digunakan seluruhnya untuk mencapai keuntungan maksimal. Besaran dual value pada lahan bayam menunjukkan bahwa penambahan luas lahan bayam sebesar $1 \mathrm{~m}^{2}$ akan menambah keuntungan petani sebesar Rp11.655. Besaran dual value pada lahan kemangi menunjukkan bahwa keuntungan petani akan meningkat sebesar Rp8.694 jika luas lahan kemangi ditambah sebesar $1 \mathrm{~m}^{2}$. Besaran dual value pada pupuk kandang menunjukkan bahwa keuntungan petani akan meningkat sebesar Rp505 jika pupuk kandang ditambah sebanyak $1 \mathrm{Kg}$ dan dual value pada pestisida callicron menunjukkan bahwa pestisida callicron yang ditambah sebanyak $1 \mathrm{ml}$ akan meningkatkan keuntungan petani sebesar Rp31.684 pada kondisi keuntungan maksimal.

Berdasarkan hasil analisis faktor produksi usahatani sayur pada setiap model tumpangsari, faktor produksi yang menjadi faktor produksi langka pada seluruh model tumpangsari adalah faktor produksi lahan. Lahan menjadi faktor produksi langka pada setiap model tumpangsari dikarenakan petani di Desa Sukorambi rata-rata memiliki lahan yang digunakan untuk kegiatan usahatani sayur kurang dari 0,1 Ha atau tergolong memiliki lahan usahatani sayur yang sempit. Hasil analisis tersebut sesuai dengan hasil penelitian yang dilakukan oleh Ansor (2016) yang menyimpulkan bahwa kendala utama petani di Desa Margamulya adalah lahan dan tenaga kerja. Hasil analisis yang diperoleh menunjukkan bahwa kendala lahan yang memiliki nilai dual price terbesar yaitu kendala lahan di lahan milik pada musim tanam 1 dan kendala lahan pada lahan sewa pada musim tanam 3 .

Hasil analisis menunjukkan perbedaan antara keuntungan petani pada kondisi keuntungan aktual dengan keuntungan petani pada kondisi keuntungan maksimal dalam satu kali tanam. Kondisi keuntungan aktual diperoleh dari hasil perhitungan sebelum dilakukan analisis sedangkan kondisi keuntungan maksimal diperoleh dari hasil perhitungan setelah dilakukan analisis. Perbedaan keuntungan tersebut dipengaruhi oleh perbedaan kombinasi tanaman sayur yang ditanam dan penggunaan faktor produksi yang digunakan pada kondisi keuntungan aktual dan kondisi keuntungan maksimal. Terdapat kombinasi sayur yang berbeda pada kondisi keuntungan aktual dan kondisi keuntungan maksimal dikarenakan setelah dilakukan analisis terdapat salah satu jenis sayur yang memiliki nilai reduced cost lebih besar dari 0, sehingga sayur tersebut tidak ditanam pada kondisi keuntungan maksimal. Faktor produksi yang menyebabkan perbedaan antara kondisi keuntungan aktual dan kondisi keuntungan maksimal adalah luas lahan sayur yang digunakan, kebutuhan bibit, pupuk, pestisida dan waktu tenaga kerja yang digunakan serta biaya-biaya yang dikeluarkan dalam kegiatan usahatani sayur tumpangsari. Perbedaan kondisi keuntungan aktual dan kondisi keuntungan maksimal usahatani sayur tumpangsari dapat dilihat pada Tabel 17.

Tabel 17. Kondisi Keuntungan Aktual dan Keuntungan Maksimal Usahatani Sayur Tumpangsari dalam Satu Kali Tanam Pada Musim Kemarau Tahun 2019

\begin{tabular}{cccccr}
\hline No & $\begin{array}{c}\text { Model } \\
\text { Tumpangsari }\end{array}$ & Aktual (Rp) & $\begin{array}{c}\text { Maksimal } \\
(\mathrm{Rp})\end{array}$ & $\begin{array}{c}\text { Peningkatan } \\
(\mathrm{Rp})\end{array}$ & $\begin{array}{c}\text { Persentase } \\
\text { Peningkatan (\%) }\end{array}$ \\
\hline 1 & Tumpangsari 1 & 264.008 .323 & 299.782 .848 & 35.774 .525 & 13,6 \\
2 & Tumpangsari 2 & 380.718 .710 & 430.256 .032 & 49.537 .322 & 13,0 \\
3 & Tumpangsari 3 & 654.014 .908 & 728.266 .632 & 74.251 .724 & 11,4 \\
4 & Tumpangsari 4 & 583.231 .708 & 675.019 .430 & 91.787 .722 & 15,7 \\
\hline
\end{tabular}

Sumber: Data Primer diolah (2019)

Berdasarkan Tabel 17 dapat diketahui bahwa keuntungan petani pada kondisi keuntungan maksimal untuk semua model tumpangsari mengalami peningkatan keuntungan dari kondisi keuntungan aktualnya. Peningkatan keuntungan pada model tumpangsari 1 sebesar Rp35.774.525 pada kondisi keuntungan maksimal. Peningkatan keuntungan pada 
model tumpangsari 2 sebesar Rp49.537.322 pada kondisi keuntungan maksimal. Peningkatan keuntungan pada model tumpangsari 3 sebesar Rp74.251.724 dan peningkatan keuntungan pada model tumpangsari 4 sebesar Rp91.787.722 pada kondisi keuntungan maksimal. Peningkatan keuntungan tertinggi pada kondisi keuntungan maksimal yaitu pada model tumpangsari 4 sebesar Rp91.787.722 atau meningkat 15,7 \% dari kondisi keuntungan aktual. Peningkatan keuntungan terendah pada kondisi keuntungan maksimal yaitu pada model tumpangsari 1 sebesar Rp35.774.525 atau meningkat 13,6\% dari kondisi keuntungan aktual. Peningkatan keuntungan pada semua model tumpangsari menunjukkan bahwa usahatani sayur tumpangsari yang dilakukan petani di Desa Sukorambi masih belum mencapai kondisi keuntungan maksimal, hal tersebut dapat dibuktikan dengan adanya peningkatan keuntungan pada seluruh model tumpangsari. Hasil analisis yang menunjukkan usahatani belum mencapai kondisi maksimal sesuai dengan penelitian yang telah dilakukan oleh Wicaksono (2006) yang menjelaskan bahwa kondisi usahatani petani luas dan petani sempit masih belum optimal dikarenakan perbandingan keuntungan antara kondisi aktual dan kondisi optimal memiliki perbandingan yang cukup besar sehingga petani dapat meningkatkan pendapatan dari kondisi aktual hingga pendapatannya optimal. Hasil analisis yang dapat digunakan dalam perencanaan usahatani sayur tumpangsari di Desa Sukorambi dapat dirangkum pada tabel berikut.

Tabel 18. Analisis Keuntungan Maksimal Usahatani Sayur Tumpangsari dalam Satu Kali Tanam Pada Musim Kemarau Tahun 2019

\begin{tabular}{|c|c|c|c|c|c|}
\hline $\begin{array}{l}\mathrm{N} \\
\mathrm{O}\end{array}$ & $\begin{array}{c}\text { Model } \\
\text { Tumpangsari }\end{array}$ & $\begin{array}{l}\text { Sayur yang } \\
\text { ditanam }\end{array}$ & $\begin{array}{l}\text { Faktor Produksi } \\
\text { Langka }\end{array}$ & $\begin{array}{c}\text { Keuntungan } \\
\text { Maksimal (Rp) }\end{array}$ & $\begin{array}{c}\text { Persentase } \\
\text { Peningkatan }(\%)\end{array}$ \\
\hline 1 & Tumpangsari 1 & $\begin{array}{l}\text { Sawi dan } \\
\text { bayam }\end{array}$ & $\begin{array}{l}\text { Lahan bayam dan } \\
\text { pupuk ZA }\end{array}$ & 299.782 .848 & 13,6 \\
\hline 2 & Tumpangsari 2 & $\begin{array}{l}\text { Sawi, bayam } \\
\text { dan } \\
\text { kangkung }\end{array}$ & $\begin{array}{l}\text { Lahan bayam, pupuk } \\
\text { kandang dan pestisida } \\
\text { callicron }\end{array}$ & 430.256 .032 & 13,0 \\
\hline 3 & Tumpangsari 3 & $\begin{array}{l}\text { Sawi, bayam } \\
\text { dan kemangi }\end{array}$ & $\begin{array}{l}\text { Lahan bayam, pupuk } \\
\text { kandang dan pestisida } \\
\text { amnistar top }\end{array}$ & 728.266 .632 & 11,4 \\
\hline 4 & Tumpangsari 4 & $\begin{array}{l}\text { Bayam, sawi, } \\
\text { kenikir dan } \\
\text { kemangi }\end{array}$ & $\begin{array}{l}\text { Lahan bayam, lahan } \\
\text { kemangi, pupuk } \\
\text { kandang dan pestisida } \\
\text { callicron }\end{array}$ & 675.019 .430 & 15,7 \\
\hline
\end{tabular}

Sumber: Data Primer diolah (2019)

Optimalisasi usahatani sayur tumpangsari di Desa Sukorambi Kecamatan Sukorambi Kabupaten Jember merupakan perencanaan usahatani yang dilakukan oleh petani di Desa Sukorambi untuk memperoleh keuntungan maksimal dengan keterbatasan faktor-faktor produksi yang tersedia. Perencanaan usahatani sayur tumpangsari dapat dilakukan oleh petani dengan mengetahui kombinasi tanaman sayur yang ditanam, penggunaan faktor produksi serta perbedaan keuntungan pada kondisi keuntungan aktual dan kondisi keuntungan maksimal. Kombinasi sayur yang ditanam pada setiap model tumpangsari adalah penanaman jenis sayur yang dapat memberikan keuntungan maksimal bagi petani dengan luas lahan yang digunakan sesuai dengan hasil analisis. Berdasarkan hasil analisis faktor produksi optimal dapat diketahui faktor produksi yang termasuk faktor produksi langka dan faktor produksi berlebih sehingga petani dapat menentukan alokasi faktor produksi yang digunakan pada setiap model tumpangsari untuk memperoleh keuntungan maksimal. Perbedaan keuntungan pada kondisi aktual dan kondisi maksimal dapat memberikan gambaran peningkatan 
keuntungan yang diperoleh pada setiap penerapan model tumpangsari yang dilakukan oleh petani. Perbedaan keuntungan pada kondisi aktual dan kondisi maksimal juga dapat diketahui apakah usahatani sayur tumpangsari yang telah dilakukan oleh petani di Desa Sukorambi telah mencapai keuntungan maksimal atau belum mencapai keuntungan maksimal. Berdasarkan hasil analisis yang telah dilakukan, petani dapat melakukan perencanaan dalam menentukan kombinasi sayur dan model tumpangsari yang akan diterapkan, pengalokasian faktor produksi yang digunakan serta jumlah keuntungan yang dapat ditingkatkan dalam kondisi keuntungan maksimal.

\section{KESIMPULAN}

Keuntungan maksimal model tumpangsari 1 sebesar Rp299.782.848 dapat diperoleh dengan menanam sayur sawi pada luas lahan $5.707 \mathrm{~m}^{2}$ dan sayur bayam pada luas lahan $14.293 \mathrm{~m}^{2}$. Keuntungan maksimal model tumpangsari 2 sebesar Rp430.256.032 dapat diperoleh dengan menanam sayur sawi pada luas lahan $10.915 \mathrm{~m}^{2}$, sayur bayam pada luas lahan $14.282 \mathrm{~m}^{2}$ dan sayur kangkung pada luas lahan $4.620 \mathrm{~m}^{2}$. Keuntungan maksimal model tumpangsari 3 sebesar Rp728.266.632 dapat diperoleh dengan menanam sayur sawi pada luas lahan $10.720 \mathrm{~m}^{2}$, sayur bayam pada luas lahan $14.418 \mathrm{~m}^{2}$ dan sayur kemangi pada luas lahan $13.849 \mathrm{~m}^{2}$. Keuntungan maksimal model tumpangsari 4 sebesar Rp675.019.430 dapat diperoleh dengan menanam sayur bayam pada luas lahan $14.337 \mathrm{~m}^{2}$, sayur sawi pada luas lahan $13.110 \mathrm{~m}^{2}$, sayur kenikir pada luas lahan $6.586 \mathrm{~m}^{2}$ dan sayur kemangi pada luas lahan $14.450 \mathrm{~m}^{2}$. Lahan untuk menanam sayur bayam merupakan faktor produksi langka pada tumpangsari model 1, 2, 3 dan 4. Lahan untuk menanam sayur kemangi merupakan faktor produksi langka pada tumpangsari model 4. Pupuk ZA merupakan faktor produksi langka pada tumpangsari model 1. Pupuk kandang merupakan faktor produksi langka pada tumpangsari model 2, 3 dan 4. Pestisida callicron merupakan faktor produksi langka pada tumpangsari model 2 dan 4. Pestisida amnistar top merupakan faktor produksi langka pada tumpangsari model 3. Keuntungan usahatani sayur tumpangsari untuk semua model tumpangsari pada kondisi keuntungan maksimal lebih tinggi dari keuntungan aktualnya. Peningkatan keuntungan tertinggi pada kondisi keuntungan maksimal yaitu pada model tumpangsari 4 sebesar Rp91.787.722 atau meningkat 15,7 \% dari kondisi keuntungan aktual. Peningkatan keuntungan terendah pada kondisi keuntungan maksimal yaitu pada model tumpangsari 1 sebesar Rp35.774.525 atau meningkat 13,6\% dari kondisi keuntungan aktual.

\section{DAFTAR PUSTAKA}

Ansor, I. R. (2016). Analisis Keuntungan Dan Optimalisasi Pola Tanam Usahatani Sayuran (Studi Kasus: Desa Margamulya, Kecamatan Pangalengan, Kabupaten Bandung). Skripsi. Fakultas Ekonomi dan Manajemen Institut Pertanian Bogor.

Badan Pusat Statistik. (2017). Survei Sosial Ekonomi Nasional Tahun 2016. Badan Pusat Statistik Republik Indonesia.

Badan Pusat Statistik. (2018). Produk Domestik Bruto Sub Sektor Hortikultura Atas Dasar Harga Berlaku. Badan Pusat Statistik Republik Indonesia.

Badan Pusat Statistik. (2018). Statistik Tanaman Sayuran dan Buah-Buahan Semusim. Badan Pusat Statistik Republik Indonesia.

Badan Pusat Statistik. (2019). Kabupaten Jember dalam Angka. Badan Pusat Statistik Kabupaten Jember.

Bungin, B. (2013). Metodologi Penelitian Sosial dan Ekonomi. Kencana Prenada Media Group. 
Dinas Pertanian. (2018). Luas Tanam Dan Produksi Sayuran Di Jawa Timur Menurut Jenis Sayuran. Dinas Pertanian Jawa Timur.

Djafri, M. S., Harianto, H., \& Syaukat, Y. (2017). Optimasi Produksi Usahatani Sayuran Organik (Studi Kasus Yayasan Bina Sarana Bakti, Cisarua, Bogor). Forum Agribisnis, 6(1), 111-129. https://doi.org/10.29244/fagb.6.1.111-129

Idani, F. R. (2012). Analisis Keuntungan Usahatani Dan Optimalisasi Pola Tanam Sayuran Di Kelompok Tani Pondok Menteng Desa Citapen, Kecamatan Ciawi Kabupaten Bogor, Jawa Barat. Skripsi. Fakultas Ekonomi dan Manajemen Institut Pertanian Bogor.

Lupiyoadi, R dan Ikhsan, R, B. (2015). Praktikum Metode Riset Bisnis. Salemba Empat.

Marzuki. (1983). Metodologi Riset. Fakultas Ekonomi Universitas Islam Indonesia.

Nazir, M. (1988). Metode Penelitian. Ghalia Indonesia.

Rianse, U. dan Abdi. (2012). Metodologi Penelitian Sosial dan Ekonomi. Alfabeta.

Sari, F. (2018). Metode Dalam Pengambilan Keputusan. Deepublish.

Wicaksono, D. (2006). Analisis Keuntungan Usahatani Dan Optimalisasi Pola Tanam Sayuran. Skripsi. Fakultas Ekonomi dan Manajemen Institut Pertanian Bogor. 